\title{
Articles
}

\section{THE CREDIT CRISIS: WHAT LESSONS FOR VISEGRAD?}

\author{
Colin Lawson, Emília Zimková*
}

\begin{abstract}
:
The origins, growth and importance of the 2007-2009 American and European credit crisis are analysed. The causes lie in the speculative bubbles, the changed attitudes to domestic property, the growth of securitisation and derivatives trading, the changing roles of financial institutions, poor policy choices and inadequate regulation. The Visegrad states are being affected by declining export markets that have triggered domestic recessions, and growing credit problems. The recession is especially penalising economies they have followed risky policies. The course of the recession is currently impossible to predict. But it is possible for these states to draw on the regulatory lessons inflicted on others, and to respond to the challenge of co-regulating the international banks that dominate their domestic markets, and which while too large to fail, are also too large to rescue unaided.
\end{abstract}

\section{Keywords:}

Bank of England; central banking; credit crisis; European Central Bank; Federal Reserve Board (US); regulation; Visegrad

\section{JEL Classification:}

$\mathrm{E} 4, \mathrm{E} 5, \mathrm{~F} 4$

\section{Introduction}

This paper explores the origins, development, and policy responses to the credit crisis that began on August $9^{\text {th }} 2007$ and exposed the USA, the UK and Eurozone to the most serious financial challenges since the Great Depression of the 1930s, and the European Central Bank (ECB) to its most difficult challenge to date. It then considers the implications for the Visegrad states, some of the most challenging of which lie in the area of central bank regulation. For central Europe the difficulties of other countries and their regulators are relatively costless case studies of what to avoid, and what to do if problems cannot be avoided. Although all the Visegrad states intend to follow Slovakia's lead and

* Colin Lawson, Matej Bel University, Banska Bystrica and University of Bath, UK (hsscwl@bath.ac.uk); Emília Zimková, Matej Bel University, Banská Bystrica, Slovak Republic (emilia.zimkova@umb.sk). 
adopt the euro, as a medium-term aim, and there is much that can be usefully learnt from others` cautionary tales.

The rest of the paper is divided into four sections. Section 2 describes the causes and spread of the credit crisis. Section 3 analyses the responses of the US Federal Reserve Board, the Bank of England and the ECB. Section 4 describes the impact of the credit crisis on Visegrad Countries, and Section 5 concludes.

\section{The Origins and Spread of the Crisis}

The credit crisis is directly attributable to the very large speculative bubbles that developed in several housing markets earlier this decade. In the United States, faced with very low growth after the end of the dot-com bubble and depressed expectations following 9/11, the then US Federal Reserve Board Chairman, Alan Greenspan, pushed US central bank interest rates down from $6.5 \%$ to $1 \%$ between 2001 and 2003 . The rate was held there and only raised in 2004-2005 as the US housing bubble inflated (Table 1). Similar bubbles developed in Ireland, Latvia, Spain and the UK, influenced in part by US interest rates but also by euro area or UK conditions.

Table 1

Interest Rates of FED

\begin{tabular}{|l|c|c|c|c|c|c|c|c|c|c|c|c|}
\hline & Jan & Feb & March & Apr & May & June & July & Aug & Sept & Oct & Nov & Dec \\
\hline 2001 & 6.50 & 5.50 & 5.50 & 5.00 & 4.50 & 4.00 & 3.75 & 3.75 & 3.50 & 3.00 & 2.50 & 2.00 \\
\hline 2002 & 1.75 & 1.75 & 1.75 & 1.75 & 1.75 & 1.75 & 1.75 & 1.75 & 1.75 & 1.75 & 1.75 & 1.25 \\
\hline 2003 & 1.25 & 1.26 & 1.25 & 1.25 & 1.25 & 1.25 & 1.00 & 1.00 & 1.00 & 1.00 & 1.00 & 1.00 \\
\hline 2004 & 1.00 & 1.00 & 1.00 & 1.00 & 1.00 & 1.25 & 1.25 & 1.50 & 1.75 & 2.00 & 2.00 & 2.25 \\
\hline 2005 & 2.25 & 2.50 & 2.75 & 2.75 & 3.00 & 3.25 & 3.25 & 3.50 & 3.75 & 3.75 & 4.00 & 4.25 \\
\hline 2006 & 4.50 & 4.50 & 4.75 & 4.75 & 5.00 & 5.25 & 5.25 & 5.25 & 5.25 & 5.25 & 5.25 & 5.25 \\
\hline 2007 & 5.25 & 5.25 & 5.25 & 5.25 & 5.25 & 5.25 & 5.25 & 5.25 & 4.75 & 4.50 & 4.50 & 4.25 \\
\hline 2008 & 3.00 & 2.25 & 2.25 & 2.25 & 2.00 & 2.00 & 2.00 & 2.00 & 2.00 & 1.50 & 1.00 & $0-0.25$ \\
\hline
\end{tabular}

Source: Federal Reserve System.

US housing prices peaked in the early summer of 2006, and the speculative bubble began to collapse. The European bubbles began to collapse at the same time, or in the following year. But lending for mortgage purposes continued at high levels, with many lenders extending loans to increasingly poor credit risks - adding to the extensive sub-prime loans they had made as the bubble had inflated (Mian, Sufi, 2008). By mid 2007 significant numbers of US sub-prime lenders were also operating extensively in the UK market, supplementing the increasingly risky loans of UK lenders.

In the US and the UK loan markets the securitization of mortgages, followed by their sale to other institutions, had provided an increasingly important source of funds to continue lending, even after the bubbles began to collapse. These mortgage-related 
bonds - a subspecies of collateralised debt obligations (CDOs) - would eventually be the vector that carried the contagion of uncertainty around the US and European banking systems. But initially they appeared to be a profitable innovation that allowed risk diversification. They were structured in such a way as to contain a range of risks, where greater risk appeared to be compensated by higher interest rates. Certified by rating agencies and insurable against default they had a wide and ready market. Many were sold to investment banks and hedge funds, which thus indirectly became major lenders in housing markets, and reflected their growing role as suppliers of credit. For example, in the US they are as important as banks in credit supply. This was to have important and unanticipated consequences when the crisis struck.

The process of creating CDOs in the US illustrates key aspects of the origins of the crisis. In recent years US mortgage lenders have become increasingly dependent on independent brokers to sell their products. The traditional mortgage lending model had been one where local bank branches sold the loan, which was then often held to maturity by the parent bank. This provided strong incentives to the bank to exercise care in assessing the creditworthiness of the borrower.

The growth in the use of independent brokers enabled banks to sell loans to a wider market at lower administrative costs. But the direct seller then had a much weaker incentive to check the borrower. The banks originating the loan could have insisted on better checks, but now they were securitising and selling the loans, so their incentive to check was also lower. The result was that loan assessment standards dropped; fewer borrowers had to provide proof of income and undoubtedly more borrowers told lies to obtain loans.

Falling loan standards should have been picked up and signalled by bond-rating companies; in the US by the three officially appointed companies: Moody's, Standard and Poor's, and Fitch. As the US housing loan market expanded rapidly these companies were in effect fulfilling or supplementing the regulatory functions of both banks and other regulators. But the bond-rating firms were only paid for their work if the bonds' originators were satisfied with their rating. This creating a clear conflict of interest between income-earning and bond-rating - a conflict heightened because bond creators could shop around between bond-rating firms for the highest rating (Lowenstein, 2008).

The CDOs were created from bonds which in turn drew on the income from pools of mortgages. Even at the first stage the credit-rating firm rated not the mortgages but the bonds issued by the special investment vehicle (SPV) created by the mortgage owners to contain them. The SPV's purpose was to sell the bonds it created and to pay for them using the income from its mortgages. The SPV issued a wide range of bonds it hoped would be rated from AAA to borderline investment grade. Its mortgage income was pooled and used to pay bond holders in the order of priority of their bonds ratings. So, if because of defaults there was an overall shortage of income, holders of lowest grade bonds suffered first; AAA holders were completely safe until all other bonds were worthless. As lower rated bonds paid higher interest rates they still had markets, provided they got a sufficiently high credit rating. The prioritisation of payments by the bonds ratings meant that the SPV could hope to issue some AAA rated bonds even though none of the underlying mortgages in themselves merited that rating. In part the skill of the lenders financial engineers lay in packaging the mortgages so as just to 
achieve the required ratings. That way they added most value to the underlying stock of their employers' subprime mortgages.

The SPV bonds were first level derivatives. In turn these bonds were used by the SPV owners to create CDOs. These second level derivatives were made up of layers of different quality SPV bonds. But CDOs could buy and sell bonds, and so because their holdings would change over time this would have made them impossibly expensive to continuously rerate. Therefore the rating agencies concentrated on the CDOs rules that limited the structure of their holdings to determine their initial rating. Third level derivatives composed of $\mathrm{CDO}$ bonds also existed. The more complex the derivative the harder was it to value, and the greater the impact of any mistakes made at the first SPV level rating. Many such first level mistakes were made. The rating agencies could point to some fraud by borrowers and lenders agents, but in addition the agencies were relying on past data to predict defaults, when the structure of the problem had changed.

The structure had changed because many more borrowers than in the past were treating housing as a speculative asset. Lenders were willing to lend even though borrowers had no equity in their houses, whereas in the past significant borrower equity was normally required to get a loan. Many borrowers were happy to take out more than one mortgage. This substantially increased the risk that a price fall would lead to negative equity and hence to the lender abandoning the property. It also meant that a check on would-be borrowers' performance on their previous primary residence mortgages was less informative than before. Now all previous mortgages needed to be checked, but rating agencies were slow to realise this (Lowenstein, 2008).

The consequence of the rating errors was severe. By early 2007 it was obvious that mortgage defaults were much higher than had been expected and finally in the spring of 2007 the rating agencies changed their models, probably at least a year after there was good evidence the models were wrong. CDO bonds issued in the early part of 2007 were reported to have lost half of their value by the end of the year. There has been no market in such bonds since August 2007, yet $\$ 200$ billion of them were created in the US in 2006-2007 alone. European banks and especially British banks also created them. Because they promised high returns and had high ratings mortgage-backed bonds were readily saleable and held widely. Thus the realisation that they were not tradable and hence could not be reliably valued spread uncertainty throughout US and European markets. Because institutions were reluctant to admit their holdings - perhaps because they could not be reliably valued - this heightened uncertainty.

It was clear that banks would have to raise huge volumes of new capital to repair the damage mortgage bonds and related derivates had caused their balance sheets, and in the US banks raised around $\$ 500$ billion of new capital even before receiving any public funds (Calomiris, 2008, p. 13). Interestingly Calomiris suggests that that fact shows that American banks were stronger than in previous financial crises, such as the 1930s or the 1980s when severe adverse selection and asymmetric information problems ruled out bank equity offerings as a solution to continuing lending. He concludes that "although it is sometimes wrongly believed that deregulation promoted bank instability, in fact subprime lending and securitisation were in no way linked to deregulation", which in fact had not occurred. 
As uncertainty spread in the six months after August 2007, failure to reveal losses provided a fertile climate to grow rumours, and for such rumours to be initiated by those hoping to profit from short selling. It is doubtful that short selling in itself was a major contributor to the crisis, rather than a useful scapegoat, diverting at least for a time attention from financial market shortcomings. But it is now clear that the unprecedented rise in spreads between overnight loans and longer-term interbank loans was substantially due to a rise in perceptions of counterparty risk (Taylor, Williams, 2009).

This perception was reinforced by the March 2008 collapse of the US broker-dealer Bear Sterns. The demise was in effect caused by a rumour-fuelled bank run in which Bear Sterns credit suppliers suddenly refused to supply any more loans. Part of their reason for pulling the plug on credit lines was their knowledge that Bear Sterns was heavily leveraged in many of its activities. In their housing market investments this meant that only modest falls in the value of the underlying assets might trigger serious losses for the company and hence in the event of defaults for its counterparties. The profit generating advantage that leveraging gave this non-regulated investment bank during a bull market, worked to its disadvantage in a bear market. The same cautionary story applied to the hedge funds that along with investment banks had become sufficiently important as suppliers of credit as to begin to overshadow traditional banks in this function. For both hedge funds and investment banks there is a strong case for a different and much tighter regulatory regime.

In the same way there is an equally strong case that assets should not be held off balance sheet, and that markets for derivatives should be regulated, and traded on exchanges. In the US and the UK and to some extent in other European states the move away from detailed regulation that has happened in some areas over the last two decades has led to the growth of a large number of assets and transactions that are not always visible in published financial data, nor indeed known to the regulatory authorities. Neither were such assets strengths and weaknesses always obvious to their owners or even perhaps to their originators. This "hidden financial economy" has not just expanded, its existence has made policy interventions more uncertain, and along with leveraging has raised the speed and scale of contagion events, and so the size of their potential costs.

The uncertainty in the mortgage bond market spread rapidly to credit card and car loan debt, and in the US rapidly raised the cost of bond issue by local and state governments and other public bodies. In other words uncertainty from the $\$ 7$ trillion US mortgage bond market spread rapidly to rest of the $\$ 27$ trillion bond stock, in an economy with an annual \$14 trillion GDP.

If the first acute phase of the crisis began in August 2007, the second acute phase was triggered by the failure of Lehman Brothers in September 2008. The US authorities decided that this investment bank was not too large to fail, and after urging it for almost a year to seek a stronger partner, to little avail as its share price drifted down, perhaps there was a feeling that its failure would be a salutary lesson to others. It turned exactly to the opposite. It was too large to fail without threatening the stability of the US financial system and then the world's financial structure. It was also too interconnected to collapse without spooking counterparties to loans throughout the banking system. The result was it failed and in the aftermath the authorities in the US, the UK, Europe and the 
wider world had to intervene to provide liquidity and fresh bank capital on an unprecedented scale.

The largest programme, the US Troubled Assets Relief Programme (TARP), began in October 2008, and by the end of the year had already completed $\$ 247$ billion transactions, including $\$ 178$ billion capital injections into banks, of which the Congressional Budget Office estimated $\$ 32$ billion were subsidy (Congressional Budget Office, 2009). But TARP programme was only the largest of a series of US Treasury and Federal Reserve responses which we touch on below. In Europe similar interventions were made in several countries, as what began as a financial crisis became a recession that now encompasses the whole world.

The financial crisis began in August 2007 when a complete loss of trust manifested itself in the widespread refusal of banks to lend to each other through the American, British and Eurozone inter-bank markets. The rates on those markets, which normally very closely tracked the central banks' lending rates, suddenly rose, creating a wedge often well in excess of 100 base points between the two rates. But despite major interventions by the central banks to provide market liquidity, by the spring of 2009 that wedge persisted, though its size had fluctuated and was somewhat reduced. But the key fact is that no central bank actions in the first twenty months of this acute phase of the crisis have yet restored commercial banks ' trust in each other. This may not return until at least the housing bubble deflations are complete, balance sheets repaired, capital replenished and strengthened, and perhaps certain types of mortgage related bonds an historical curiosity. By that time the IMF has projected a possible $\$ 1$ trillion loss for banks from the crisis (IMF, 2008). Others expect banks losses to be much higher, for example Nouriel Roubini the now respected New York University analyst estimates that for US financial firms the sum of total loan losses and the fall in the market value of their assets will reach $\$ 3.6$ trillion (New York Times, February 13, 2009). Half of the losses will impinge on US banks, and the remainder on other US financial firms and abroad. "The United States banking system is effectively insolvent," he was reported as saying. Equally apocalyptically the Bank of England director of Financial Stability Andrew Haldane has said that banking losses now "lie anywhere between a very large number and an unthinkable one" (Haldane, 2009). But bank and other financial losses will still be dwarfed by the output losses that only started to be noticed in the final quarter of 2008 .

\section{Central Banks Responses}

The credit crisis posed difficult problems for central banks - if only because it clearly exposed weaknesses in other regulators, and limitations to central bank powers of intervention. In addition there is a strong case that the US Federal Reserve actions in 2001-2005 added to the housing speculative bubble, and also that it could and should have intervened earlier to head off the crisis.

The ECB, the Bank of England and the Federal Reserve Board all have the key responsibility of safeguarding the integrity of their respective financial systems. But when it comes to specific institutions, for example banks, regulatory authority varies and clarity fades. For example we have already noted that the Federal Reserve regulates neither investment banks nor hedge funds, but only limited types of deposit takers. In 
the Eurozone financial institutions are regulated by national authorities that employ a wide range of different models (Table 2). Traditionally, different sectors of financial systems (e.g. deposit institutions, insurance companies, and capital markets) were regulated by different institutions. This is the so-called sectoral model. But as financial institutions started to provide integrated financial services, for example loans and insurance, they had to be regulated simultaneously by several authorities. Consequently since the 1980 s there has been a trend towards creating integrated national regulatory institutions that supply regulation and supervision to all financial institutions.

Figure 1

Inauguration Dates for the Integrated Supervision of Financial Markets



Source: Houben, A., 2006, p. 3.

Table 2 shows that the majority of EU countries already apply the integrated supervision model (15:10). In eleven EU states integrated supervision is not a central bank responsibility. Only in four of the smaller countries - Iceland, Holland, Slovakia, and the Czech Republic - does the central bank supply integrated supervision to financial markets. 
Table 2

Models of Financial Markets Regulation in EU Member Countries

\begin{tabular}{|c|c|c|c|c|}
\hline \multirow[t]{2}{*}{ Country } & \multicolumn{3}{|c|}{ Financial sectors of regulation } & \multirow[t]{2}{*}{ Characteristics } \\
\hline & $\begin{array}{l}\text { Depository } \\
\text { institutions }\end{array}$ & Insurance & $\begin{array}{c}\text { Capital } \\
\text { markets }\end{array}$ & \\
\hline Belgium & \multicolumn{3}{|c|}{ RI } & Integrated model outside $\mathrm{CB}$ \\
\hline Cyprus & $\mathrm{CB}$ & RI & RI & Sectoral model \\
\hline Czech Republic & \multicolumn{3}{|c|}{$\mathrm{CB}$} & Integrated model within $\mathrm{CB}$ \\
\hline Denmark & \multicolumn{3}{|c|}{ RI } & Integrated model outside $\mathrm{CB}$ \\
\hline Estonia & \multicolumn{3}{|c|}{ RI } & Integrated model outside CB \\
\hline Finland & RI & RI & RI & Sectoral model \\
\hline France & RI & RI & RI & Sectoral model \\
\hline Greece & $\mathrm{CB}$ & RI & RI & Sectoral model \\
\hline Netherlands & \multicolumn{3}{|c|}{$\mathrm{CB}$} & Integrated model within $\mathrm{C}$ \\
\hline Ireland & \multicolumn{3}{|c|}{$\mathrm{CB}$} & Integrated model within $\mathrm{C}$ \\
\hline Lithuania & $\mathrm{CB}$ & RI & RI & Sectoral model \\
\hline Latvia & \multicolumn{3}{|c|}{ RI } & Integrated model outside $\mathrm{CB}$ \\
\hline Luxembourg & \multicolumn{3}{|c|}{ RI } & Integrated model outside $\mathrm{CB}$ \\
\hline Hungary & \multicolumn{3}{|c|}{ RI } & Integrated model outside $\mathrm{CB}$ \\
\hline Malta & \multicolumn{3}{|c|}{ RI } & Integrated model outside $\mathrm{CB}$ \\
\hline Germany & \multicolumn{3}{|c|}{ RI } & Integrated model outside $\mathrm{CB}$ \\
\hline Poland & $\mathrm{CB}$ & RI & RI & Sectoral model \\
\hline Portugal & $\mathrm{CB}$ & RI & RI & Sectoral model \\
\hline Austria & \multicolumn{3}{|c|}{ RI } & Integrated model outside $\mathrm{CB}$ \\
\hline Slovakia & \multicolumn{3}{|c|}{$\mathrm{CB}$} & Integrated model within $\mathrm{CB}$ \\
\hline Slovenia & $\mathrm{CB}$ & RI & RI & Sectoral model \\
\hline Spain & $\mathrm{CB}$ & RI & RI & Sectoral model \\
\hline Sweden & \multicolumn{3}{|c|}{ RI } & Integrated model outside $\mathrm{CB}$ \\
\hline Italy & $\mathrm{CB}$ & RI & RI & Sectoral model \\
\hline Great Britain & \multicolumn{3}{|c|}{ RI } & $\begin{array}{l}\text { Integrated model outside CB } \\
\text { (FSA) }\end{array}$ \\
\hline
\end{tabular}

Abbreviation: $\mathrm{CB}$ - central bank, RI - other regulatory institution.

Source: Zimková, E., Vargová, V., 2006, p. 19.

In the UK banks are regulated by the Financial Services Agency (FSA), and the regulatory regime for the financial sector also includes the Treasury as well as the Bank of England. In the process of dealing with the fallout from the nationalisation of the Northern Rock Bank - whose reliance on inter-bank borrowing doomed it after August 2007 - it became clear that while the main regulatory failure was the FSA's, this tripartite system of regulation had failed to work properly in its first significant test since 
its 1997 creation. There is currently no plan to reform the UK`s regulatory model, for example by allowing the Bank of England to close a bank it judges to be effectively insolvent. That reflects the UK governmental position that the design of the regulatory system is effective, although the FSA may have been at fault in its performance during the pre-crisis and early-crisis periods. This is in large part a politically convenient fiction.

The Federal Reserve reacted to the August 2007 crisis with innovative policies mainly involving accepting mortgage backed products in return for short run government paper. This addresses the liquidity issue caused by the vanishing CDO market. At the same time banks were encouraged to raise more capital, and many have done so. When Bear Sterns' lenders vanished the Federal Reserve encouraged a takeover by another bank. But because part of the price for the takeover was state guarantees of up to $\$ 29$ billion of assets, this was met by the US Treasury, being beyond the resources and the legitimate scope of the central bank. But since then, and arguably even before then the Federal Reserve Board has shown invention and determination in trying to expand the range of monetary policy tools at its command (Bernanke, 2009). But with interest rates effectively zero there is, apart from quantitative easing - in effect printing money - a dearth of untried policies. So, as insuring toxic assets has, as in the UK, been preferred to bank nationalisation and the use of a "bad bank" into which to move those assets before state recapitalisation, monetary policy is fully extended and fiscal policy is from now on where the innovations need to be sought.

The US Congress is exploring changes to the numerous regulatory regimes covering financial institutions, markets and products. All that is clear is that regulations and regulators had not evolved sufficiently to handle the changes in market institutions, products and practices that could cause instability. The crisis has exposed gaps in regulatory coverage and to help close these gaps by taking a system level view a single over-arching regulatory agency is being suggested. This proposal is supported by Bernanke, and the Federal Reserve is the obvious candidate to fill the position because of the scope of its current remit.

The ECB has since its inception had a more activist role in Eurozone markets than has either the Federal Reserve or the Bank of England in their home markets. As soon as the credit crisis broke the ECB pumped 95 billion euros into the Eurozone banking system; accepting in return a wide range of assets including mortgage related bonds. Until recently neither the FED nor the Bank of England would have considered many of these assets of sufficiently high quality to act as collateral for loans. In fact in 2008 the ECB had to redefine the kind of assets it would accept as collateral after it emerged that some borrowers were restructuring assets into the most risky category that would be accepted. Since then the ECB has continued to provide short-term liquidity on a very substantial scale, but has continued to rely on national authorities to sort out institutional regulatory issues.

Although the Eurozone banking system has continued to function, its inter-bank markets have not returned to low spreads seen before the crisis began. Nor will they do so until mortgage backed, and other doubtful assets are fully disclosed, convincingly valued, and accepted as being no further danger to their holders. For some mortgage backed assets and other derivatives, that may require their extinction.

The ECB was not just slow to reduce interest rates it increased them as late as July 2008. Like the Bank of England it was so slow to respond to evidence of recession that 
when the rates were cut they could only help repair rather than prevent the damage. This sloth in part reflects the ECB's focus on inflation, and in part its strong independence that allows it to pursue policies that others oppose. For the former reason the ECB has so far opposed the policy of quantitative easing, or printing money, that the Bank of England began in March 2009.

The Bank of England played a rather passive role in the credit crisis until April 2008. It had provided $Ł 4.4$ billion extra liquidity in September 2007, followed by further injections of $€ 10$ billion three-month funds in December 2007 and January 2008, and Ł15 billion in April 2008. But then it announced that from 21 ${ }^{\text {st }}$ April 2008 a Special Liquidity Scheme of $€ 50$ billion of government bonds would be made available for up to three years and could be borrowed against mortgage or credit card related bonds (Bank of England, 2008). The facility was originally a short-term policy, but has now been extended at least until the end of 2009 and considerably increased in scope. In effect the scheme provides not only liquidity, but can also help banks get certain unwanted assets off their balance sheets. The Bank will accept AAA assets backed either by residential mortgages or by credit card debt. If the assets are down-rated the borrowing banks would have to replace them in the swop arrangement with other AAA assets, or return some of their borrowings. The assets must be based on loans made before 2008, and none of the assets can be based on derivative products or on US mortgages. To guard the taxpayer against borrower default the assets are discounted by between $10 \%$ and $30 \%$, as well as an interest charge imposed.

The Bank of England was very slow to recognise the importance of dropping interest rates, but between October 2008 and March 2009 it cut them to 0.5\%. But although borrowing rates fell the LIBOR spread did not return to pre-crisis levels and UK output, along with US and Eurozone GDPs fell rapidly. The response in March 2009 was to begin printing money: quantitative easing. This involves the Bank buying government debt and high-class commercial paper. This provides liquidity and reduces longer-term interest rates, so flattening the yield curve. The problems include which money supply definition to target; what the velocity of circulation is; and which assets to buy. But the impact on the money supply may eventually be considerable, because the Bank is authorised to spend up to 150 billion pounds - equivalent to $10 \%$ of UK GDP. But if this does not lead to growth then there are currently no more monetary policies to try, and only fiscal policy may be effective.

We noted above that there is a strong argument that unless toxic assets cease to be viewed by lenders as a problem for their holders then the financial system will cease to function well. There are two possible solutions. One is to create a special vehicle to hold the assets, separate from the bank that originally owned them. This could involve nationalising those banks with significant amounts of such assets, because they may be reluctant to sell them at realistic prices, in order to preserve the appearance of solvency. The other is for the government to insure the assets against loss, so drastically reducing any uncertainty about the value of the insured bank. The UK has chosen this route, by March 2009 insuring 585 billion pounds worth of assets for two large banking groups. The banks have to absorb less than the first $10 \%$ of losses, after which $90 \%$ of further asset losses are covered. The premium for the insurance was derisory-not least because it was paid in shares whose value is doubtful. The UK taxpayers' maximum loss is about $30 \%$ of GDP. This is a very risky solution for the taxpayer, and reflects a failure of political 
will to apportion the losses caused by those banks by nationalising them, or by allowing them to fail. The key message for other countries is that after the Lehman's debacle we need to create ways to manage the bankruptcy of large financial organisations, without risking financial panic or placing extraordinary risks on taxpayers.

\section{The impact of the Credit Crisis on Visegrad Countries}

The Visegrad agreement created a regional alliance to promote political stability, economic growth and prosperity by strengthening social and economic cooperation between the Czech Republic, Hungary, Poland and Slovakia. The process of transformation at the end of the last century has not only brought prosperity to their people but it has also opened up opportunities for international financial markets and investors. International financial institutions (especially banks from Austria, Germany, France and Italy) recognised the enormous growth potential of the Visegrad nations and took part in the privatisation of financial institutions. Before the privatisation the balance sheets of banks in all Visegrad countries were cleaned up by political decision and their bad loans became a part of the public finances. Recapitalizing financial institutions, the development of effective capital market regulation and many structural reforms have paved the way for stable financial systems with well-capitalized banks and a growing number of institutional investors in the form of newly created insurance and pension companies.

The financial markets of Visegrad countries have benefited from economic liberalisation coupled with foreign direct investment, which injected capital, managerial know-how, and new technology. The economic growth of the Slovak, Czech and Polish economies was rather robust. Since 2007 Hungarian economic growth had been deteriorating.

Initially these figures compared favourably to the United States and the euro area but as there are no realistic untapped export markets, and all group members save Poland are necessarily heavily export oriented the slump will likely be as severe in Visegrad states as in their main export markets (Table 3).

Table 3

GDP Growth in Analysed Countries

\begin{tabular}{|c|c|c|c|c|c|c|c|c|c|c|c|}
\hline & 2000 & 2001 & 2002 & 2003 & 2004 & 2005 & 2006 & 2007 & 2008 & 2009 & 2010 \\
\hline Euro area & 3.9 & 1.9 & 0.9 & 0.8 & 2.1 & 1.7 & 2.9 & 2.6 & 0.8 & $\begin{array}{r}\text { n.a. } \\
*-3.2\end{array}$ & $\begin{array}{l}\text { n.a./ } \\
* 0.4\end{array}$ \\
\hline $\begin{array}{l}\text { Czech } \\
\text { Republic }\end{array}$ & 3.6 & 2.5 & 1.9 & 3.6 & 4.5 & 6.3 & 6.8 & 6 & 4.4 & $\begin{array}{r}3.6 / \\
*-3.00 \\
\end{array}$ & $\begin{array}{r}3.9 / \\
* 0 \\
\end{array}$ \\
\hline Hungary & 5.2 & 4.1 & 4.1 & 4.2 & 4.8 & 4 & 4.1 & 1.1 & 0.5 & $\begin{array}{r}0.7 / \\
*-4.5\end{array}$ & $\begin{array}{r}1.8 / \\
*-0.5\end{array}$ \\
\hline Poland & 4.3 & 1.2 & 1.4 & 3.9 & 5.3 & 3.6 & 6.2 & 6.6 & 4.8 & $\begin{array}{r}3.8 / \\
*-1.0\end{array}$ & $\begin{array}{l}4.2 / \\
* 2.2\end{array}$ \\
\hline Slovakia & 1.4 & 3.4 & 4.8 & 4.7 & 5.2 & 6.5 & 8.5 & 10.4 & 6.4 & $\begin{array}{r}4.9 / \\
\text { n.a }\end{array}$ & $\begin{array}{r}5.5 / \\
\text { n.a }\end{array}$ \\
\hline USA & 3.7 & 0.8 & 1.6 & 2.5 & 3.6 & 2.9 & 2.8 & 2 & 1.1 & $\begin{array}{r}-0.5 / \\
*-2.5\end{array}$ & $\begin{array}{r}1 / \\
* 1.9\end{array}$ \\
\hline
\end{tabular}

Source: Eurostat. 2008-2010 are Eurostat forecasts. *J. P. Morgan forecasts. 
In the period 2004-2008 strong growth in three of the four Visegrad countries created an increased demand for capital much of which was raised locally by the branches and subsidiaries of Eurozone banks. All central banks of the Visegrad countries operate sterilisation policies to neutralise potentially inflationary financial flows. In the banking sector since the restructuring and recapitalisation of banks' balance sheets there has been adequate liquidity, and the local branches of international banks have not needed to borrow from European markets, where the costs of inter-bank loans have steadily grown.

Nevertheless the seeds for financial crises were planted by cheap and readily available credit. In addition Hungary had problems with controlling fiscal deficits. This contributed to relatively high interest rates in local currencies and so an incentive to borrow in foreign currencies, where much lower interest rates were available. By 2009 most of Hungarian household debt and about a third of Polish household debt was denominated in foreign currencies. The Czech Republic had virtually no such borrowing, and Slovakia's January 2009 accession to the euro area limited the problematic nature of such debts, as the forint and the zloty rapidly depreciated against the euro in the second half of 2008.

The Western European banks that dominate lending to Central and Eastern Europe (CEE), were not lending responsibly by encouraging foreign currency denominated loans. To be mutually profitable such loans require stable exchange rates. Yet the main reason why interest rates were higher in CEE domestic currencies was their higher inflation rates. So such borrowing could only be relatively safe over the short run, and refinancing costs and even the availability of credit became increasingly unpredictable as the credit crisis developed in 2007-2008. The truth is that much of CEE had the preconditions for a classic financial crisis before the shock of the credit crisis hit. As in Western Europe the idea that the crisis was a wholly foreign import is a fiction. The pattern is similar in all economies: financial crises involve a splurge of borrowing and spending on easy terms, followed by a shock and then by a painful period of deleveraging (Reinhart, Rogoff, 2008).

The credit crisis has raised a regulatory problem that Visegrad states may need to address in future, and so would benefit from discussing it in advance. The crisis has shown the growing interconnectedness of modern capital markets, but also that it is possible for the US Federal Reserve, the ECB and the Bank of England to at least roughly coordinate their liquidity supply responses. But the banks that have failed have all been national rather than international. Thus the relevant national regulators and their taxpayers have naturally and so far willingly shouldered the burden. The problem is what to do when in future an international bank fails, for as we have noted there is no agreed procedure for solving a cross-border crisis. The example of Fortis, a Dutch-Belgium-French bank illustrates the problem. After it became in effect insolvent in 2008 the three governments nationalised the parts of the bank that fell within their jurisdictions, but the negotiations were imperfectly coordinated, key decisions were sometime made unilaterally and several attempts to resolve disagreements were needed before the process was completed.

Most of the banks that operate in Visegrad states are international. On the eve of the crisis in 2006 the share of foreign-owned banks by assets was $97 \%$ in Slovakia, $85 \%$ in the Czech Republic, $83 \%$ in Hungary and $74 \%$ in Poland (EBRD, 2007). The banks are 
headquartered in Austria (most importantly), Italy, France, Belgium, Germany and Sweden. By 2009 their loans to CEE were around 1.3 trillion euros and most of the key lenders had already received some recapitalisation from their home governments.

In addition while credit default swaps originators and ratings agencies could distinguish between the different banks and the different prospects of the Visegrad states, there was a well founded fear that contagion stemming from weaker CEE states would damage the whole region`s prospects as capital was withdrawn back to its sources.

The problems are to assign responsibility for regulation, and for intervention, including any necessary costs. The crisis has shown that large banks are no less vulnerable than small ones, and saving a large international bank would require coordinated action and deep pockets. Because bank interventions need to be done quickly this would require activating prior agreements, hence the need for a formal framework. In April 2008 the EU finance ministers agreed to closer monitoring of cross-border banks, but this is just the first stage of formulating and constructing an adequate crisis intervention system. The logic of a single European market leads inexorably towards a single regulatory system, if not a single regulator. The dangers of a fragmented response in a Europe of several dozen states are obvious, and it would be a missed opportunity if Europe took as long as the United States to develop an effective regulatory regime.

Yet in practice it seems that a fragmented response is the most likely outcome to a large bank's failure, with the burden of costs apportioned in an ad hoc case-by-case manner. This could be a problem for Visegrad states because the formal commitments of parent Western European banks depend on whether they do their business through branches or subsidiaries. If the latter, then they have no legal requirement to cover shortfalls beyond the amount of the equity capital they have invested. In fact most Western European banks in CEE do their business through subsidiaries.

\section{Conclusion}

This paper has examined the origins, growth, transmission and consequences of the current credit crisis. It has argued that the crisis began in a series of loosely connected speculative bubbles in domestic property markets in several countries, but most importantly the United States. The nature of the demand side of those markets had been somewhat changed by the increasingly speculative motives of a growing number of participants. But fuelling the boom were exceptionally low interest rates, and a lowered perception of risk on the part of financing institutions, driven not just by the normal search for profits but also reassured by the growing ease of securitising the increasingly risky loans they were supplying. That securitisation was the vector through which risks, and later, losses were to infect the balance sheets of a wider and wider range of institutions and so eventually to trigger the first global recession since the 1930s.

There were three critical episodes before the financial crisis and the subsequent recession became global. The first was the disappearance of the interbank markets in August 2007. The second was the debacle of Bear Sterns in the spring of 2008. The third was the near collapse of the global financial system after the failure of Lehman Brothers in September 2008. In the first, trust between banks disappeared. In the second the 
authorities acted to ensure a rescue as counterparty trust almost evaporated. In the third a misguided attempt to avoid the moral hazard of a rescue almost destroyed depositors` trust in the financial system. Since then although the authorities have tried with some success to coordinate monetary policy, and bank bailouts in Europe and North America have preserved much of the public utility parts of commercial banking, the solution to the toxic assets problem is still elusive. In part this is because of a failure of political leadership to recognise that the separation of toxic assets from the banks is an essential precondition of recovery. Meanwhile a signal failure to coordinate a global fiscal stimulus, or in the case of many countries a more basic failure to understand why it is needed, has condemned the global economy to plummet to the bottom of whatever depression lies in front of it. Until it hits the bottom the degree of toxicity of the financial sector's assets will be unknowable.

For the Visegrad states there is much that can be learned from these crises. For example there are the lessons of regulation that seem to need to be relearned at least once a generation. It is good that financial systems innovate, but bad if the new products damage the public utility aspects of commercial banking. Also firm governance is a key area for reform, but not one where there are obviously good models that can be immediately adopted. Also it is clear that both banks and states should build reserves pro-cyclically, as cushions against losses and to allow fiscal stimuli in recessions.

Visegrad states experiences show two additional and specific pressing problems that need solutions. The first one is how to signal that they are well run, and so avoid contagion from other emerging markets. Obviously and as a minimum that requires consistent sound policy decisions and their implementation. But contagion is not a wholly rational phenomenon, so membership of the euro area is a strong contender to strengthen the signal by capturing the credibility of a key global currency.

Secondly, it is the issue of foreign ownership of the banking system. There is a clear need for explicit and open arrangements on a country to country, and bank to branch or subsidiary basis to ensure that there are no uncertainties about the level of support that will be forthcoming in the event of crisis. Again euro area membership would provide a stronger signal, but it is not a substitute for credible undertakings, the lack of which has unnecessarily damaged the image of Visegrad`s financial sectors.

\section{References}

Bank of England (2008), Special Liquidity Scheme: Information. www.bankofengland.co.uk/ markets/sls/sls-information.pdf.

Bernanke, B. S. (2009), "The Crisis and the Policy Response" Remarks by Ben S. Bernanke, Chairman, Board of Governors of the Federal Reserve System at the Stamp Lecture, London School of Economics, January 13, 2009.

Calomiris, C. W. (2008), "Banking Crises", NBER Reporter, No. 4, pp. 10-14.

Congressional Budget Office (2009), The Troubled Asset Relief Program: Report on Transactions Through December 31, 2008. January 2009. Washington DC: Congressional Budget Office.

European Bank for Reconstruction and Development (2007), Transition Report 2007. London: EBRD.

European Central Bank (2008), Financial Stability Review, December 2008. Frankfurt am Main: ECB. 
Haldane, A. G. (2009), "Why Banks Failed the Stress Test" Paper delivered at the Marcus-Evans Conference on Stress-Testing, 9-10 February 2009. http://www.bankofengland.co.uk/publications/ speeches/2009/speech374.pdf.

Houben, A. (2006), "Towards an Integrated Supervisor: Experience from the Netherlands“. Power Point Presentation, World Bank, Washington, 2006. http://info.worldbank.org/etools/docs/library/ 232488/Houben\&Geskes_Netherlands.ppt\#3.

International Monetary Fund (2008), Global Financial Stability Report. April 2008, Washington DC: IMF.

Lowenstein, R (2008), "Triple-A Failure". New York Times Magazine, April $27^{\text {th }} 2008$.

Mian, A., Sufi, A. (2008), "The Consequences of Mortgage Credit Expansion: Evidence from the 2007 Mortgage Default Crisis". Cambridge MA. National Bureau of Economic Research Working Paper No. 13936.

Reinhart, C. M., Rogoff, K. S. (2008), "Banking Crises: an Equal Opportunity Menace”. Cambridge MA. National Bureau of Economic Research Working Paper No. 14587.

Taylor, J. B., Williams, J. C. (2009) "A Black Swan in the Money Market". American Economic Journal: Macroeconomics. 1 (1), pp. 58-83.

Zimková, E., and Vargová, V. (2006), "Trendy v inštitucionálnom usporiadaní finančnej regulácie a dohl'adu v Európskej únii“. Biatec, 5/2006, pp. 18-22. 